Article

\title{
Embedding Product-Service System of Cutting Tools into the Machining Process: An Eco-Efficiency Approach toward Sustainable Development
}

\author{
Cledson Oliveira Lanzilotti ${ }^{1}$, Luiz Fernando Rodrigues Pinto ${ }^{1} \mathbb{D}$, Francesco Facchini ${ }^{2, *}$ (D) and Salvatore Digiesi ${ }^{2} \mathbb{D}$ \\ 1 Industrial Engineering Post-Graduation Program, Universidade Nove de Julho (UNINOVE), \\ Liberdade 01504-001, Brazil; eng_cledson@yahoo.com (C.O.L.); lfernandorp44@gmail.com (L.F.R.P.) \\ 2 Department of Mechanics, Mathematics and Management, Polytechnic University of Bari, 70125 Bari, Italy; \\ salvatore.digiesi@poliba.it \\ * Correspondence: francesco.facchini@poliba.it
}

Citation: Lanzilotti, C.O.; Pinto, L.F.R.; Facchini, F.; Digiesi, S.

Embedding Product-Service System of Cutting Tools into the Machining Process: An Eco-Efficiency Approach toward Sustainable Development. Sustainability 2022, 14, 1100. https:/ / doi.org/10.3390/su14031100

Academic Editors: Vikas Kumar, Geraldo Cardoso de Oliveira Neto, Wagner Cezar Lucato and Marlene Amorim

Received: 15 December 2021

Accepted: 17 January 2022

Published: 18 January 2022

Publisher's Note: MDPI stays neutral with regard to jurisdictional claims in published maps and institutional affiliations.

Copyright: (C) 2022 by the authors. Licensee MDPI, Basel, Switzerland. This article is an open access article distributed under the terms and conditions of the Creative Commons Attribution (CC BY) license (https:// creativecommons.org/licenses/by/ $4.0 /)$.

\begin{abstract}
Product-Service System (PSS) is a sustainable strategy that shifts the focus of the business from selling physical products to providing service by using the product. The innovation proposed in the PSS, focused on sustainable production and consumption, is consistent with the sustainable development goals of the United Nations 2030 Agenda. The scientific literature on PSS in machining showed studies that address the economic factor of PSS contract, machine maintenance and logistics and operational process improvement. Then, there is a lack of studies on the assessment of the PSS in machining under a sustainability factors perspective. Thus, the objective of this paper was to evaluate the economic, environmental, and social advantages of PSS cutting tools in machining. Consistent with this aim, the research focused on a case study in a diesel engine parts machining company. From an economic point of view, the results indicated a reduction in operating costs of US\$1,206,080 per year, which allowed a nine-month return on investment. From an ecological perspective, the recovery of $602 \mathrm{~kg}$ of carbide per year mitigated the environmental impact of tungsten and cobalt exploration. These results are even more expressive because it deals with scarce metals. Furthermore, technological advances reduced the risk of injury to operators. This research increased knowledge on PSS in machining by presenting an original study that led the analysis under a sustainability perspective. Moreover, this study contributes to managers by showing the business model's advantages that reduce operating costs and socio-environmental impacts, enhancing sustainable development.
\end{abstract}

Keywords: product-service system; cleaner production; sustainable development; cutting tool; machining

\section{Introduction}

Product-Service System (PSS) has been adopted in several business sectors that seek to develop sustainable business models, based on consumption and production, which support the transition towards cleaner production and circular economy [1]. PSS is a sustainable strategy that shifts the focus of the business from selling physical products to providing service for product use, which are more eco-efficient in terms of resource optimization [2]. PSS contractors can reduce costs and increase productivity through valueadded services [3]. PSS providers are required to add more value to the products they offer and augment and diversify the services related to these products [4]. While PSS, on the one hand, strengthens the link between supplier and customer, which contributes to improving competitiveness, on the other hand, the personalized product service makes it difficult to replace supplier [5]. Nevertheless, in most cases, PSS has shown sustainable benefits that offer win-win relationship to service providers and customers $[6,7]$. 
The search for studies in the literature on PSS in machining identified articles that addressed this theme. Four studies address the economic factor of PSS contracts in machining. A framework for quantifying the uncertainties in the cost-benefit estimation of machine tool PSS contracts was provided in [8]. Zhang et al. [9] developed a method based on Pareto principles to evaluate the economic viability of PSS CNC machines. Similarly, a cutting tool condition monitoring model to increase the quality and profit of PSS cutting tools and a PSS cost estimation scheme of cutting tools have been introduced in [6] and [3], respectively.

Four other studies addressed PSS in machine maintenance. In 2021, Chang et al. [10] provided a framework for maintenance decision-making oriented on CNC machine services. Wang et al. adopted an active preventive maintenance approach of PSS-based CNC machines [1]. A model that integrates the PSS of machining machinery maintenance was developed by considering the availability of repair and machine parts [11]. Similarly, Wang et al. [12] introduced a collaborative maintenance planning system integrated into the machine tool PSS model.

Two studies developed PSS models focused on logistics and operational process improvement. A cutting tool PSS model based on demand prediction and just-in-time tool delivery [13] and a PSS framework of CNC machines, hardware, and software was introduced based on availability and machining capability improvement [14].

Although the approach of PSS in machining was detailed in the mentioned research, there isn't a study that evaluated the economic, environmental, and social gains of PSS in machining. The previous papers focus on the economic aspect, while the environmental and social factors were neglected in the studies about PSS in machining. The research gap identified in the literature suggested the following question: the PSS in machining can be an eco-efficient alternative for sustainable development in the industry? To provide an answer to the question raised, this research aims to evaluate the economic, environmental and social advantages of PSS cutting tools in machining.

These benefits, achieved through the modernization of production processes, led to an increase of the eco-efficiency adopting a strategy consistent with sustainable development goals, \#9 (Industry, innovation and infrastructure) and \#12 (sustainable production and consumption), defined in the 2030 Agenda prepared by the United Nations Organization [15]. The process modernization is consistent with the concept of cleaner production, which contributes to increasing the competitiveness of companies through the reduction of cost and environmental impact [16-19]. In this perspective, suppliers adopting the environmental practices allow supporting the companies in the business to achieve sustainable development goals [20]. Economic growth, ecosystem conservation and human welfare are the basis to achieve sustainability objectives [21,22]. However, there is no clear evidence of the effects of PSS in the industry on sustainability performance [23]. These facts enhance the contribution of a study that measures the benefits of PSS cutting tools in machining under a sustainability perspective.

This research adopted the case study methodology with a quantitative approach to evaluate the benefits of PSS in a diesel engine parts machining company. This is an innovative approach that embedded the sustainability factors into the assessment of PSS cutting tool in machining process of engine parts. The diesel engine has several applications such as power generators, automotive, tractors, and marine [24]. The advantages of diesel engine generators have increased considerably for different reasons such as high level of reliability, high speed at performance as well as easy implementation in the isolated hybrid microgrids [25]. The diesel engine is being further developed to compete with other power sources as the engine is advantageous regarding logistics, storage, efficiency and compactness [26].

The economic assessment consisted of payback analysis based on operational costs and investment of PSS implementation. In terms of the environmental factor, the mass balance of recycling cutting tools at the end of service life. Cutting tools are produced adopting scraps of raw materials such as tungsten and cobalt. The tungsten carbide endows 
the alloy an excellent hardness and superior wear resistance [27]. The excellent cutting and wear resistance properties of its carbides have made it a strategic commodity of high importance globally, highly employed in the manufacturing, petrochemical, construction, gas drilling and mining sectors [28]. These elements are fundamental to promoting global industrial and technological development [29]. There is a real risk due to metal scarcity and to the impact of exploration of these metals involving geopolitical risk and human rights abuse [29]. Therefore, recycling and the technical loops are strategies to ensure resource availability over time [30]. The social factor analysis considered the improvements to reduce the ergonomic risks.

The motivation of this research is to offer a work not yet developed in the literature on the economic, environmental, and social advantages of PSS in machining. In addition, this study intends to encourage industrial managers to seek PSS businesses that increase the eco-efficiency of their production processes, such as cleaner production practices towards sustainable development. Top management should increase creative process engagement among employees as it is a crucial intangible resource for green process [31].

This article is structured as follows: The systematic review of the literature is presented in Section 2, in which the PSS in machining is explored in depth. The research methodology is shown in Section 3. The economic, environmental and social evaluations of PSS in an engine parts machining industry are conducted in Section 4 . The discussions of the case study results and the findings of the theoretical basis are shown in Section 5. Finally, Section 6 highlights the conclusions, contributions of the work, limitations, and future research suggestions.

\section{Literature Review}

The systematic literature review identified a sample of 10 articles on PSS in machining. The scope of the search and the selection criteria used are presented in the methodology section. The approach adopted in selected papers is related to PSS economic analysis, CNC machine maintenance, and logistical and operational process improvement.

The studies focused on the economic aspects, evaluated the PSS contracts' economic feasibility, cost-benefit, and uncertainties. In this context, Farsi and Erkoyuncu [8] presented a framework to quantify machine tool PSS contracts' uncertainties under an economic perspective. The model estimates the machine's service life cost, including the PSS contracts based on service level and on spare parts availability. Several parameters were considered in the analysis of cost-benefit uncertainty, such as machine acquisition price, rental/leasing, assembly, and disassembly of the machine in the customer, installation, testing, maintenance and retrofit. The results highlighted that the PSS is advantageous in long-term contracts. Zhang et al. [9] developed a method based on Pareto principles to evaluate the economic viability of PSS of CNC machines. The CNC machine has been deployed in the physical and service modules.

The first includes body, tool holder, spindle, tailstock, hydraulic and electrical parts. The second module includes human-computer interaction, debugging service, machine maintenance, installation, emergency rescue, remote service, test, and quality assurance. Both modules' integrated analysis allowed the engineers to identify the customer needs and deliver the best deal. Zhang and Sun [6] have developed a cutting tool condition monitoring model to increase the PSS quality and the profitability in this business. Despite the positive expectation about monitoring cutting tool conditions, improvements to the Tool Condition Monitoring (TCM) system have been identified. The quality of service depends on the accuracy, reliability and robustness of the functions of the TCM system, which are very limited. Moreover, it was highlighted the unavailability of the cutting tool services in real-time due to the complexity of the TCM system. In this regard, the integration of the Internet of Things (IoT) and a cloud manufacturing service system could substantially improve the performance of the TCM system. Mu et al. [3] developed a method of estimating the PSS cost of cutting tools, oriented on activity-based costing. The activities raised by the study were machining, management, maintenance and repair 
operations. The pricing parameters of the service include time-consumed tools and labour costs. Machining and repair activities were associated with tool consumption, while management and maintenance to labour costs.

Chang et al. [10] developed a framework for decision making in the maintenance of $\mathrm{CNC}$ machine services based on a distributed blockchain network. Implementing a collaborative sharing environment allowed to improve the diagnose failures and manage PSS resources for CNC machine maintenance. In this framework, stakeholders' involvement from different organizations allows broadening the knowledge to implement proactive performance-based maintenance PSS planning. Similarly, Wang et al. presented a PSS approach to preventive maintenance of $\mathrm{CNC}$ machines adopting Industry 4.0 technologies. CNC machines were distributed to customers, and a service provider monitored their activities. A neural network was trained to predict the rest of the service life of the main machine components, which increased the accuracy of prediction, improved preventive maintenance planning, and reduced costs and resource consumption [1]. A model to link a combination of CNC honing machines with similar functions in a service network [11]. The network analyzes the machine availability identifying failures and critical nodes, with the aim to optimize the execution of maintenance services. Wan et al. [12] investigated the relationships between different stakeholders in the life cycle of machine tools to develop a collaborative machine tool maintenance planning system. The sharing of production planning information and machine conditions between users and machine tool manufacturers allowed to schedule a maintenance planning optimizing the number of parts to repair and replace, ensuring a high service level and low operation costs.

The PSS model of cutting tool proposed by Sun et al. [13] was oriented to predict demand and just-in-time delivery of tools. The research jointly analyzes three aspects: the cutting tool selection, the demand prediction, and the cutting tool delivery. The results showed that outsourcing management of cutting tools reduces costs and improves productivity. Zhu et al. [14] presented a PSS framework of CNC machines, hardware, and software, based on machining capability and continuous improvement. The framework introduced changes the role of machine tool vendors to machining capability suppliers, involving machine operation, repair, and maintenance. The innovative business, not yet familiar to companies of this segment, combined with the lack of protection of technological intellectual property, were barriers to the implementation of PSS proposed by the study.

The main information of the collected articles are described in Table 1.

Table 1. Articles identified in the systematic literature review on PSS in machining.

\begin{tabular}{cccccc}
\hline Authors & Year & Title & Journal & Country & Methodology \\
Approach
\end{tabular}


Table 1. Cont.

\begin{tabular}{|c|c|c|c|c|c|c|}
\hline Authors & Year & Title & Journal & Country & Methodology & $\begin{array}{c}\text { PSS } \\
\text { Approach }\end{array}$ \\
\hline Zhang et al. & 2019 & $\begin{array}{l}\text { Extraction of association rules in } \\
\text { the schematic design of product } \\
\text { service system based on } \\
\text { Pareto-MODGDFA. }\end{array}$ & $\begin{array}{l}\text { Computers \& } \\
\text { Industrial } \\
\text { Engineering }\end{array}$ & China & Case study & $\begin{array}{l}\text { Economic } \\
\text { analysis }\end{array}$ \\
\hline Chang et al. & 2018 & $\begin{array}{l}\text { A function availability-based } \\
\text { integrated product-service } \\
\text { network model for high-end } \\
\text { manufacturing equipment. }\end{array}$ & $\begin{array}{l}\text { Computers \& } \\
\text { Industrial } \\
\text { Engineering }\end{array}$ & China & Case study & Maintenance \\
\hline Zhang and Sun & 2018 & $\begin{array}{l}\text { Enabling a cutting tool iPSS based } \\
\text { on tool condition monitoring. }\end{array}$ & $\begin{array}{l}\text { Int. J. Adv. } \\
\text { Manuf. Tech. }\end{array}$ & China & Experiment & $\begin{array}{l}\text { Economic } \\
\text { analysis }\end{array}$ \\
\hline Wan et al. & 2017 & $\begin{array}{l}\text { Process and knowledge } \\
\text { management in a collaborative } \\
\text { maintenance planning system for } \\
\text { high value machine tools. }\end{array}$ & $\begin{array}{l}\text { Computers in } \\
\text { Industry }\end{array}$ & China & Case study & Maintenance \\
\hline Sun et al. & 2016 & $\begin{array}{l}\text { Cutting-tool delivery method in } \\
\text { the context of industrial product } \\
\text { service systems. }\end{array}$ & $\begin{array}{l}\text { Conc. Eng. } \\
\text { Research \& } \\
\text { Applic. }\end{array}$ & China & Case study & $\begin{array}{l}\text { Process } \\
\text { improvement }\end{array}$ \\
\hline Mu et al. & 2012 & $\begin{array}{l}\text { Machining process level cost } \\
\text { estimation in cutting-tool IPSS. }\end{array}$ & $\begin{array}{l}\text { Applied Mech. } \\
\text { and Materials }\end{array}$ & China & Case study & $\begin{array}{l}\text { Economic } \\
\text { analysis }\end{array}$ \\
\hline Zhu et al. & 2011 & $\begin{array}{l}\text { Implementing an industrial } \\
\text { product-service system for CNC } \\
\text { machine tool. }\end{array}$ & $\begin{array}{l}\text { Int. J. Adv. } \\
\text { Manuf. Tech. }\end{array}$ & China & Experiment & $\begin{array}{l}\text { Process } \\
\text { improvement }\end{array}$ \\
\hline
\end{tabular}

The search in the databases considers the publication' year as an open field. Therefore, the evidence that the selected articles have been published in the last 10 years denotes the PSS in machining as a contemporary theme. The little amount of research on PSS in machining showed the opportunity to investigate this research area. The environmental and social factors are two aspects outside the PSS analysis conducted in the published studies. This lack highlights the contribution of this research including the sustainability factors in PSS analysis in machining.

\section{Materials and Methods}

The data analyses conducted adopts a quantitative and qualitative approach. The case study facilitated the understanding of the subject in practice to favour the critical analysis of the background theory [32].

The planning and execution of the case study followed the five steps defined by Yin [33]: (i) problem definition; (ii) research delineation; (iii) data collection; (iv) data analysis; (v) results. The first step in a case study consists of defining the research problem. The second stage refers to the methods adopted to carry out the case study and identify the aspects out of the research scope. The third stage consists of collecting the data that occurred in this study through semi-structured interviews, observation of the production process and management reports. The fourth stage is data analysis, in which economic, environmental and social evaluations were carried out. The fifth step suggests the analysis of the results, which in this research led to checking if the PSS in machining is an eco-efficient alternative for sustainable development in the industry.

The definition of the research problem was performed through a bibliometric and systematic literature review. A bibliometric survey quantifies the scientific literature on a specific topic [34], through which it is possible to identify empirical data that can be displayed in predefined selection settings [35]. The results of the bibliometric research can be systematically reproduced [36]. Therefore, the compilation of relevant information on a given subject becomes strategic for future studies related to the topic researched [37]. Di 
Vaio et al. [38] recommend four steps to guarantee a reliable systematic literature review that involves: (1) extraction of articles from databases, (2) identification of relevant articles, (3) manual localization of highly cited articles and (4) identification of other influential articles. With this, the bibliometric and systematic literature review ensured that the studies included in the research theme had been selected. The literature's research aimed to identify articles related to PSS, cleaner production, and machining in the present work. Bardin [39] recommends seeking papers using keywords, analyzing the found articles and choosing those that are relevant to the study. For this scope, a set of keywords was defined to identify documents in the scientific databases: Scopus, ScienceDirect, Web of Science and Wiley. The search has been conducted based on preliminary information collected through Scopus, which is the largest database with multidisciplinary scientific literature analysis tools [40]. The Science Direct, Web of Science and Wiley electronic databases were also selected due to their relevance to the theme and research field [41]. The keywords were combined into pairs, as shown in Table 2.

Table 2. Keywords used in the search engine and the number of articles.

\begin{tabular}{ccccc}
\hline Keywords Combination & Scopus & ScienceDirect & Web of Science & Wiley \\
\hline $\begin{array}{c}\text { "Product-service system" or } \\
\text { "PSS" and "cleaner production" }\end{array}$ & 14 & 8 & 1 & 0 \\
\hline $\begin{array}{c}\text { "Product-service system" or "PSS" } \\
\text { and "machining" }\end{array}$ & 23 & 15 & 0 & 0 \\
\hline $\begin{array}{c}\text { "Product-service system" or } \\
\text { "PSS" and "cutting tool" }\end{array}$ & 7 & 0 & 0 & 0 \\
\hline
\end{tabular}

The search of the databases was carried out in August 2021. All documents nonrefereed as scientific documents (journal articles), such as conferences, books, and magazines, were excluded from the initial search in the scientific database [42,43]. The total number of documents that combined the terms shown in Table 2 in the title was 68 articles. A spreadsheet was used to record the main information of the selected documents. The next step was to remove duplicate documents; 11 repeated articles were identified. The list of 57 papers is presented in Appendix A. The number of papers by year of publication is shown in Figure 1.

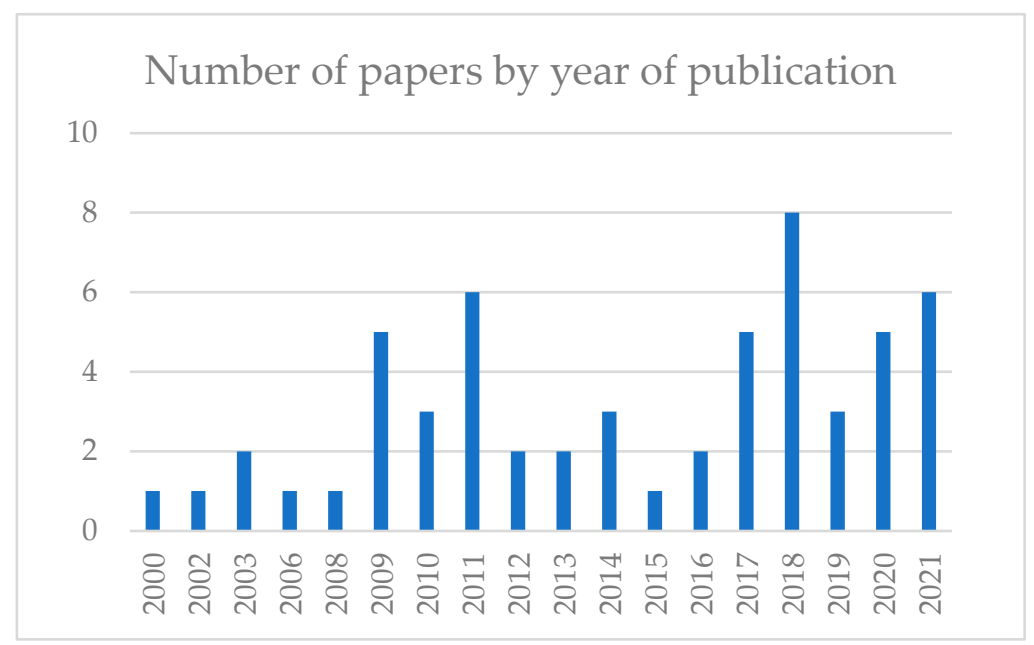

Figure 1. Number of papers by year of publication.

The content analysis followed the procedure of Del Giudice et al. [44] that recommends each author proceed initially with the content analysis by reading the abstracts and, after that, the entire document analysis for papers related to the research objectives. The analysis 
of the remaining 57 studies revealed that 47 studies addressed PSS in other areas such as household appliances [45], construction [46], truck maintenance [47], tourism [48], food and beverage sales machines [49], waste management [50] and aircraft [51]. Thus, the selection of scientific papers identified 10 articles on PSS in machining. According to the Preferred Reporting Items for Systematic reviews and Meta-Analyses (PRISMA) method [35], the selection criteria used in the search for articles were summarized in Figure 2.

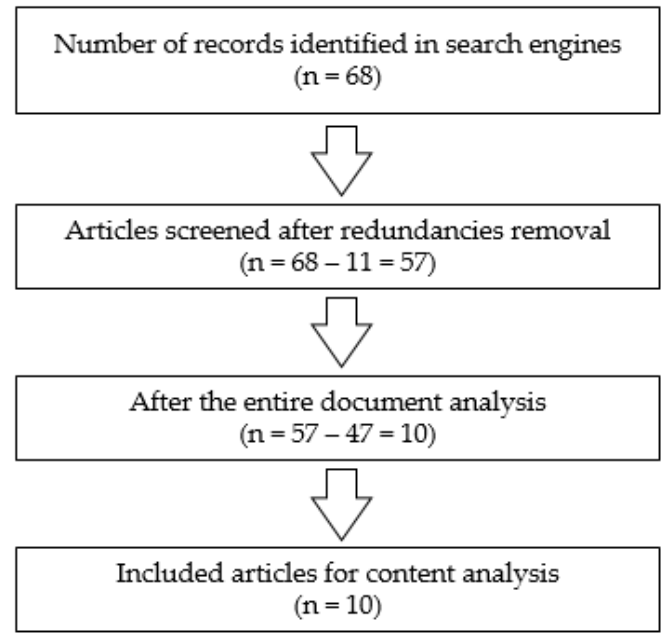

Duplicates $=11$

Out of the core theme $=47$

Figure 2. Stages of selection of articles in the literature. Source: Adapted from Moher et al. [35].

The analysis of the 10 articles allowed to consolidate the theoretical foundation of this study that supported the field research carried out in a process of machining diesel engine parts. Data collection was conducted by observing the production process, analyzing documents and interviewing technicians and managers of the companies involved in the PSS contractor.

The collected data allowed evaluating the advantages due to PSS implementation. The PSS implementation required a previous period to monitor and analyze the machining process in special cutting tool conditions to establish the monetary values of the business agreement. The cutting tool condition monitoring was performed by Zhang and Sun [6] to increase the PSS quality and the profitability in this business. The economic analysis considers operational costs, cutting tool consumption, revenue from cutting tool recycling and investments to assess the economic viability of PSS implementation in machining. These parameters were defined based on the analysis of Mu et al. [3] that estimated the PSS cost of cutting tools. The literature on PSS in machining did not approach the environmental and social factors. For this reason, usual methods to quantify environmental and social impacts were adopted in this study. In environmental terms, the benefits to the ecosystem were measured by analyzing the mass balance of the recycling of cutting tools at the end of service life. Social advantages were related to occupational health and safety in terms of ergonomic risks reduction in the washing of tools. The Humantech software was used to calculate the ergonomic risk score.

\section{Results}

PSS analysis in machining was conducted in a diesel engine industry in São Paulo/Brazil. The factory has a quality management system (ISO 9001), environmental (ISO 14001) occupational safety and health (OHSAS 18001) certifications. Leadership stimulates its employees' professional and personal development as a human resources practice.

\subsection{Presentation of the Production Process}

The factory's production process consisted of four machining lines composed of manual machines, semi-automatic and $\mathrm{CNC}$ machining centres. Material handling between 
machines is carried out by adopting unpulled roller tracks. The processing time from the raw part input to the output of the finished product is approximately $10 \mathrm{~h}$.

Tool management considers two tool stocks: circulating and new. The first tool stock includes circulating, in-edging or preparation tools. The stock of new tools is adopted to replace the rolling tools at the end of service life.

Cutting errors are key factors to monitor for predicting the quality of the finished product. Cutting tool wear requires periodic changes to avoid quality issues such as scrap, rework. Monitoring the tools service life has been ensured by recording specific data and promptly signalling the tool change needed to the operators.

The complexity of tool acquisition flow strongly affected the machining performance. In this regard, the requests for new tools enter the purchase queue and require three managers' quotations and authorization. The various stages of this process take an average of seven days to complete. Another aspect that makes it difficult to manage tools is that the large number of suppliers lead to congestion in tool delivery tasks.

About the equipment for sharpening and preparing tools has emerged that these tasks are very complex and require highly skilled workers.

\subsection{The PSS Implementation}

A PSS contract has been suggested to the company's managers by the tooling supplier. The prospect of increased production demand and consequent consumption of tools, combined with failures of inventory management of tools and specialized labour to prepare tools, motivated the interest in the new business model.

Evaluating tools wear related to the service life of tools was key to identifying the tool consumption and the respective cost per part produced. Implementing RFID technology in tool management increased the reliability of the tools' information logging and consumption control. The preliminary analysis phase of the PSS lasted five years. In this period, the knowledge of the process was deepened, reducing the price uncertainties of the PSS and strengthening the trust of the customer-supplier relationship. From the PSS agreement signed, the client company has left the management of cutting tools in charge of the supplier. In the PSS, instead of buying the tool, the customer paid an agreed amount of tool consumption per piece produced.

In addition to the use of a tool, the PSS contract included the provision of specialized labour services in preparation, edging, material purchase, inventory control, engineering support, and productivity improvements related to cutting tools in the machining process.

The service life and the corresponding acquisition cost vary according to the type of tool. The tool life was defined according to practical tests performed in the machining process. Experts conducted tests on all tools repeated three times in each operation to analyze the machining process variations. The service life is given from the average of the three values measured reduced of a "safety factor" (i.e., $2 \%$ ) introduced to avoid tool breakage and product quality problems. The service life information allows estimating the number of parts produced with the same tool. Therefore, the cost of tool per piece (CPP) was estimated according to Equation (1).

$$
\mathrm{CPP}=\sum_{\mathrm{t}=1}^{\mathrm{n}} \frac{\text { Tool cost }}{\text { Tool life }}
$$

where:

" $\mathrm{t}$ " represents the number of produced parts with a tool [unit];

"Total cost" is the cost of the tool considered [US\$];

"Tool life" identify the number of cycles performed by the tool before replacing [cycle].

An example of a part requiring 81 types of cutting tools to be machined is shown below (Table 3). 
Table 3. Cost per piece of each tool.

\begin{tabular}{|c|c|c|c|c|c|}
\hline ID Code & Description & Qty [u] & $\begin{array}{l}\text { Tool Life } \\
\text { [Cycle] }\end{array}$ & $\begin{array}{c}\text { Tool Cost } \\
\text { [US\$] }\end{array}$ & $\begin{array}{c}\text { Cost per Piece } \\
\text { [US } \$ / \mathbf{u}]\end{array}$ \\
\hline \#01 & Drill Ø20 mm & 1 & 282 & 136.00 & 0.48 \\
\hline \#02 & Countersink tool Ø15 mm & 1 & 1120 & 558.00 & 0.50 \\
\hline$\# 03$ & Step drill Ø4.5 mm & 1 & 4000 & 320.20 & 0.08 \\
\hline \#04 & Blade $32 \mathrm{~mm}$ & 1 & 340 & 29.70 & 0.09 \\
\hline \multirow[t]{2}{*}{ \#05 } & Drill $\varnothing 8.5 \mathrm{~mm}$ & 1 & 1760 & 294.50 & 0.17 \\
\hline & $\ldots$ & 1 & $\ldots$ & $\ldots$ & $\ldots$ \\
\hline \multirow[t]{2}{*}{$\# 81$} & Reamer $22 \mathrm{~mm}$ & 1 & 2000 & 220.00 & 0.11 \\
\hline & Total & & & & 14.60 \\
\hline
\end{tabular}

The cost of US $\$ 14.60$ per piece represents the amount that the tool supplier will receive from the customer for each part produced on the machining line. In this example, assuming a scenario in which the annual volume of production is 20,000 pieces, the cost of cutting tools would be US\$292,000 per year or US\$ 5615.38 per week. The tool consumption cost is weekly estimated, according to the production of seven days, aiming to mitigate production fluctuation in relation to the annual planning. The withdrawal of tools from stock to production takes place adopting a requisition that generates the issuance of an invoice. The cost of specialized labour for the management and preparation of tools was US\$ 50,200 per month.

\subsubsection{Tool Preparation in PSS}

Old machines were adopted to prepare the tools. The tool supplier diagnosed the obsolescence of available machines, requiring the sector's modernization for the PSS implementation. Therefore, an investment of US\$ 820,000 was needed to acquire new machines and upgrade the available equipment. The preparation of tools was installed in the centre of the factory to facilitate the access and service to machining. Experts in cutting tools (employees of supplier) supporting machining process in production shifts are available on-site. In addition to infrastructure improvements, the control of readiness data has been modernized. The installation of RFID chips in tools allowed the storage and easy access to pre-set information, tool life, and tool identification. Therefore, when the tool in the $\mathrm{CNC}$ machining centre is installed, the data stored on the chip are automatically transferred to the machine without the intervention of the operator. This feature automatically loads the machining process at the end of the cutting tool service life, reducing tool breaks and product quality issues. In PSS, the tool replacement time was shortened from seven days to $20 \mathrm{~min}$. The technician produces a requisition that contains the description of the tool and the reason for the reset. After the Production Leader has been approved, the technician registers the requisition in the tool management system and automatically removes a new tool from inventory.

\subsubsection{Tool Inventory Management}

The stock of tools is composed of new and circulating tools. A machine called Vending Machining (VM) manages 70\% of items and could allocate more than 600 items such as inserts, blades, drills, and taps. VM works as a vendor sales station located in the tool preparation room. The tool requisition is electronically registered in the system, issuing an invoice, and sending it to the customer for weekly settlement with the supplier.

The minimum number of tools in stock has been identified for each item to avoid a lack of tools. Upon reaching the minimum stock, the system automatically generates a purchase order and sends it to the tool supplying plant to arrange inventory replacement. The tool requisition and reset steps are shown in Figure 3. 


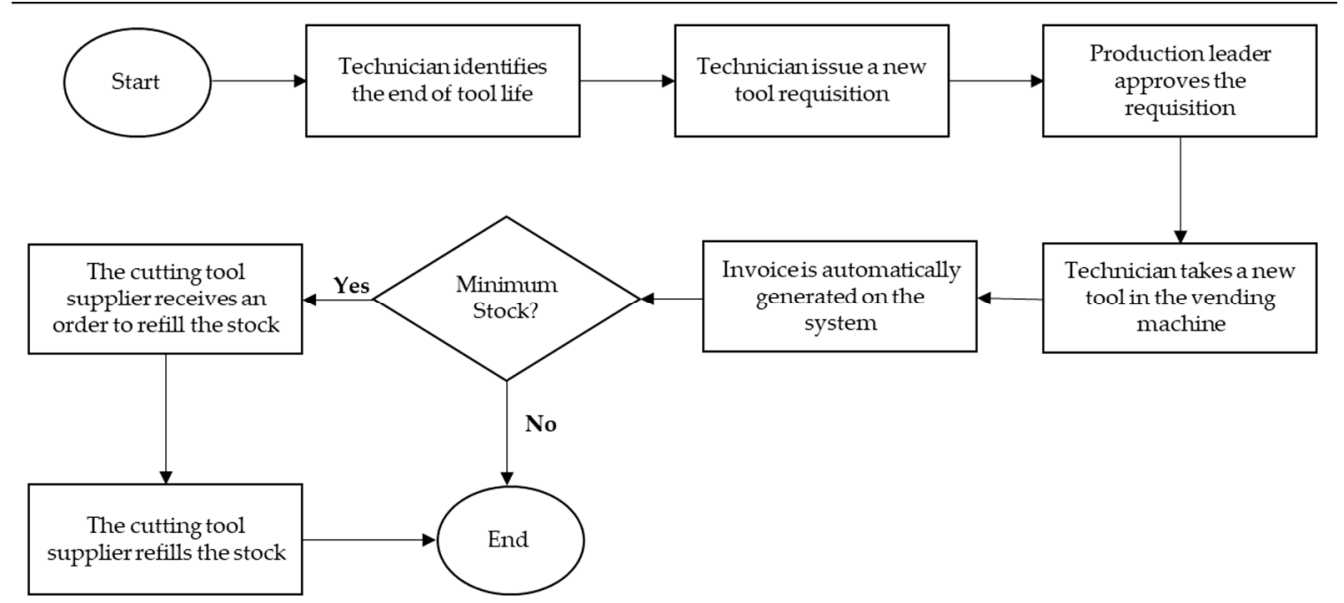

Figure 3. Tool requisition and retooling steps. Source: Elaborated by the author.

\subsection{Economic Assessment}

The economic feasibility of the business model was assessed to evaluate the ecoefficiency of the PSS in machining. The investment consisted of the tool preparation room, equipped with: two core sharpeners; three rapid steel, carbide and lapping grinders; one multi-sharpener; two tool presetters; one cylindrical grinder; two flat grinders; one automatic washer; two granite tables (straightening). The total investment in machinery and equipment was US\$ 820,000.

The machining cost reduction has been evaluated considering the entire PSS process, from tool stock management to tool consumption in production. In the PSS, the supplier ensures US\$1360,000 immobilized in tool stock. Where the tools included in the circulating stock (in the process) account for US\$ 560,000 of the total tools stocked. The tool consumption for the annual production volume of 20,000 pieces was estimated at US\$ 880,000 per year. The labour cost in inventory management and tool preparation was reduced from US\$ 794,880, before the PSS implementation, to US\$ 602,400 adopting the PSS. The recovery of metallic tool material due to recycling of cutting tools at the end of service life provided revenue of US\$ 5600 per year to the company. A summary of the data analyzed for the economic evaluation is provided in Tables 4 and 5.

Table 4. Economic evaluation before and after PSS implementation.

\begin{tabular}{|c|c|c|c|c|}
\hline Description & Before [US\$] & After [US\$] & Annual Saving [US\$] & Monthly Saving [US\$] \\
\hline Cost of cutting tool inventory & $1,360,000.00$ & 0 & & \\
\hline Cost of cutting tool consumption & $680,000.00$ & $880,000.00$ & & \\
\hline Cost of cutting tool in process & $408,000.00$ & $560,000.00$ & & \\
\hline Labor & $794,880.00$ & $602,400.00$ & & \\
\hline Revenue from recycling & 0 & $-5,600.00$ & & \\
\hline Total & $3,242,880$ & $2,036,800.00$ & $1,206,080.00$ & $100,506.67$ \\
\hline
\end{tabular}

The implementation of the PSS led to an annual reduction of US\$1,206,080 in operating cost per year, or US\$100,506.67 per month. The payback calculation indicated that the investment of US\$ 820,000 due to modernization of the tool preparation room will be recovered in nine months. 
Table 5. Cash flow due to PSS implementation.

\begin{tabular}{|c|c|c|c|c|c|}
\hline Cash Flow & Month 0 & Month 1 & Month 2 & Month 3 & Month 4 \\
\hline Total investment & $-820,000.00$ & & & & \\
\hline Additional net profit & & $100,506.67$ & $100,506.67$ & $100,506.67$ & $100,506.67$ \\
\hline Accumulated net cash flow & $-820,000.00$ & $-719,493.33$ & $-618,986.67$ & $-518,480.00$ & $-417,973.33$ \\
\hline $\begin{array}{c}\text { Cash flow } \\
\text { Total investment }\end{array}$ & Month 5 & Month 6 & Month 7 & Month 8 & Month 9 \\
\hline Additional net profit & $100,506.67$ & $100,506.67$ & $100,506.67$ & $100,506.67$ & $100,506.67$ \\
\hline Accumulated net cash flow & $-317,466.67$ & $-216,960.00$ & $-116,453.33$ & $-15,946.67$ & $84,560.00$ \\
\hline
\end{tabular}

\subsection{Environmental Assessment}

The cleaner production practice incorporated into PSS tool management allowed the recycling of tool material at the end of service life. This action contributed to the reduction of the extraction of virgin material and to the conservation of the ecosystem. The material of cutting tools is composed of $81 \%$ Tungsten, $13 \%$ Cobalt and $6 \%$ Carbon.

The mass balance analysis identified $602 \mathrm{~kg}$ of material destined for recycling in 2020. Therefore, the recovered cutting tools reduced the yearly exploitation of $487.6 \mathrm{~kg}$ of tungsten and $78.3 \mathrm{~kg}$ of cobalt. This result is even more expressive because it deals with scarce metals.

\subsection{Social Assessment}

The social factors were assessed considering the PSS implementation in machining. In particular, the tool washing activities involved health risks for operators due to ergonomics and chemical handling. The tools to be prepared should be washed in advance to remove a semi-synthetic metalworking fluid used in the machining process. According to the cutting tools supplier, the lubricant fluid specification was suitable for its purpose. It has an essential role in improving the surface finish of parts and extending tool life. The fluid was Quakercool 3605 BFF water-soluble. Before PSS implementation, the washing of the tools occurred in a reservoir in which the operator used a hose with a squirt and bristling brush. According to experts, these tasks produce efforts in the arms region at risk of injury. In this regard, the modernization that occurred with the implementation of the PSS provided a reduction in the risk to human health.

A washer machine automatically cleans and dries the tool in the new process. The operator works in the supply and removal of parts from the machine. With this, human contact with the chemical agent was eliminated and, efforts in the arms were significantly reduced.

The advantages achieved for human health were evaluated by Risk Priority Score (RPS) estimated adopting a software used in ergonomic analysis. The comparative risk analysis before and after the PSS implementation is shown in Figure 4.

\begin{tabular}{|c|c|}
\hline Previous & After \\
\hline $\begin{array}{c}\text { Risk Priority Score } \\
\text { (RPS) }\end{array}$ & $\begin{array}{c}\text { Risk Priority Score } \\
\text { (RPS) }\end{array}$ \\
\hline 18
\end{tabular}

Figure 4. Ergonomic Evaluation. Source: Elaborated by the author. 


\subsection{PSS Opportunities and Threats in Machining}

Company managers have positively evaluated the PSS. The increase in technical knowledge due to the incorporation of tools' experts in the production process provided economic, environmental, and social gains.

However, the PSS risk factors were raised to mitigate a negative impact on business. One aspect mentioned by managers is that the technical knowledge of cutting tools was under the supplier's domain. Moreover, although the supplier is a world reference in the manufacture of cutting tools, there is a risk of limitation to the technologies adopted.

In addition, considering the vulnerability of technical knowledge, there is a risk related to the financial capacity of the supplier. The threat to the company arises from the possibility of the supplier going bankrupt or giving up the business. The impact on financial risk was mitigated by contract clauses that define the supplier's obligation to approve another supplier of cutting tools to meet the customer's demand. In addition, periodic meetings between the senior management of the companies are conducted every six months to present the results, including the supplier's financial condition.

\section{Discussion}

The results of this study showed that the diagnosis of technological lag in the preparation of tools, elaborated by the supplier, opened the mind of the senior management to the need for investments in this area. The acquisition of machinery and equipment increased the reliability of tool preparation, reducing non-quality costs and ensuring technicians safer operation. With this, PSS in machining proved to be aligned with advances in sustainable development. This finding corroborates the study by Oliveira Neto et al. [15] on machine modernization as a strategy aimed at sustainable development goals, \#9 (Industry, innovation and infrastructure) and \#12 (sustainable production and consumption) of the United Nations agenda 2030.

The previous analysis period to PSS implementation was fundamental to improving knowledge on the production process. In this stage, the conditions monitoring of machining and tool preparation provided data that made it possible to establish the fair cost of tool per piece for both buyer and supplier. This finding corroborates Zhang and Sun [6] that developed a cutting tool condition monitoring model to increase the PSS quality and the profitability in this business.

Another fact was the reduction of production downtime due to the lack of a cutting tool. This achievement was due to the responsibility of cutting tools management move from customer to supplier. The supplier's stock at the customer site reduced communication noise, increased the sense of priority and the availability of cutting tools. The outsourcing management of cutting tools reduces costs and improves productivity [13].

Another positive aspect linked to PSS was the implantation of cleaner production practices in machining. The uniqueness in supplying tools increased the attractiveness of hard metal recycling. The sale of the recovered material at the end of life (before the PSS implementation was discarded), is an additional revenue and reduces the extraction of virgin raw material. The conservation of the ecosystem carried out by reducing environmental impact is inserted in the companies' environmental policy focused on this study. Therefore, the involvement of suppliers adopting environmental practices helped both related companies in the business achieve sustainable development goals, as stated by Oliveira Neto et al. [20].

The economic evaluation conducted in this study considered an investment for the implementation of the PSS, including labour, inventory costs and tools consumption. This information was fundamental to evaluating the economic viability of the PSS. The method used in this research converges with the PSS costs estimation introduced by Mu et al. [3], in which the pricing parameters were evaluated considering the same item costs.

Despite the economic assessment showing the return on investment within nine months, PSS is usually characterized by long-term contracts. PSS is based on trust, enhancing the importance of buyers and suppliers seeking to strengthen dialogue and cooperation 
to reduce business uncertainties. The PSS risk management mentioned by managers in the case study revealed the business model's concern. PSS contracts' uncertainties were analyzed by Farsi and Erkoyuncu [8] that highlighted that PSS is advantageous in long-term contracts.

The advantages achieved highlighted a strong relationship with the tools supplier led to improving the eco-efficiency of machining. The economic viability of the PSS presented in this work revealed that the payment for the use of the tools instead of its acquisition reduced inventory cost, inventory replacement time and reduced the risk due to lack of tools.

\section{Conclusions}

This study achieved its objective of evaluating the economic, environmental, and social advantages of PSS cutting tools in machining. The results indicated that the PSS in machining is an eco-efficient alternative for sustainable development in the industry. The PSS reduced the operating cost of US\$1,206,080 per year, which allowed the return on investment in nine months. In addition, recycling $602 \mathrm{~kg}$ of carbide per year reduced the extraction of scarce metals in nature, such as tungsten and cobalt. Furthermore, technological advances reduced the risk of injury to operators. These advantages shown that PSS in machining is a cost-effective business model that provides environmental and social benefits.

These findings denoted that PSS cutting tools in machining meets two sustainable development goals. The evidence of goal number 9 (industry, innovation and infrastructure) achievement was the modernization of the tool preparation room. The acquisition of new machines and equipment increased the productivity of tool preparation. Furthermore, the RFID technology implementation improved the data reliability of the stock management system and reduced product quality issues. The other goal, number 12 (responsible consumption and production), highlighted the optimization of cutting tool consumption and the recycling of cutting tools at the end of the life cycle.

The theoretical contribution of this research was to provide a work not yet detailed in the scientific literature on the economic, environmental, and social advantages of PSS in machining. PSS as a contemporary business model should fulfil the sustainability requirements demanded by stakeholders. However, the systematic literature review on PSS in machining identified that environmental and social factors were neglected in published studies. This finding shows the opportunity for future research to investigate the socioenvironmental implications of PSS in the machining process. Moreover, an in-depth analysis can reveal that PSS drives sustainable development in other industrial sectors.

As a contribution to corporate practice, this study aims to encourage industrial managers to seek PSS businesses that increase the eco-efficiency of their production processes. The dissemination of this work can reach managers of suppliers and customers and encourage them to promote strategies aimed at replacing product ownership with the service of their use. The approximation of business partners with socio-environmental goals allows a synergy between factories to implement cleaner production practices aimed at sustainable development.

The exploratory purpose of this research limited its findings to the company focused on the study. The method and data collected do not allow the generalization of the results. Another limitation of this study is the focus on sustainable development goals \#9 (industry, innovation and infrastructure) and \#12 (responsible consumption and production). These goals are related to industrial activity. In this sense, future studies should explore PSS in machining under different perspectives taking into account other goals defined by the United Nations Organization. In addition, future research should be addressed to more extensive studies, where a great number of companies should be included. Moreover, more deep knowledge about PSS in machining advantages should promote sustainable development, considering all supply chain stakeholders. 
Author Contributions: Conceptualization, C.O.L., L.F.R.P., F.F. and S.D.; formal analysis, F.F. and S.D.; investigation, C.O.L., L.F.R.P.; writing—original draft preparation, C.O.L., L.F.R.P.; writing-review and editing, F.F. and S.D.; supervision, L.F.R.P.; project administration, L.F.R.P. All authors have read and agreed to the published version of the manuscript.

Funding: This research was funded by the Coordination for the Improvement of Higher Education Personnel (CAPES) of the Federal Government of Brazil.

Institutional Review Board Statement: Not applicable.

Informed Consent Statement: Not applicable.

Data Availability Statement: Not applicable.

Conflicts of Interest: The authors declare no conflict of interest.

\section{Appendix A}

Table A1. List of papers found in literature review about PSS and cleaner production.

\begin{tabular}{|c|c|c|c|c|}
\hline \# & Authors & Article Title & Journal & Year \\
\hline 1 & Pecorari, P.M.; Lima, C.R.C. & $\begin{array}{l}\text { Correlation of customer experience with the } \\
\text { acceptance of product-service systems and } \\
\text { circular economy }\end{array}$ & $\begin{array}{l}\text { Journal of Cleaner } \\
\text { Production }\end{array}$ & 2021 \\
\hline 2 & $\begin{array}{l}\text { Chiu, M.; Huang, J.; Gupta, S.; } \\
\text { Akman, G. }\end{array}$ & $\begin{array}{c}\text { Developing a personalized recommendation } \\
\text { system in a smart product service system based } \\
\text { on unsupervised learning model }\end{array}$ & Computers in Industry & 2021 \\
\hline 3 & Farsi, M.; Erkoyuncu, J.A. & $\begin{array}{l}\text { Na agent-based approach to quantify the } \\
\text { uncertainty in product-service system contract } \\
\text { decisions: a case study in the machine tool } \\
\text { industry }\end{array}$ & $\begin{array}{l}\text { International Journal of } \\
\text { Production Economics }\end{array}$ & 2021 \\
\hline 4 & $\begin{array}{c}\text { Bu, L.; Chen, C.; Ng, K.; } \\
\text { Zheng, P.; Dong, G.; Liu, H. }\end{array}$ & $\begin{array}{c}\text { A user-centric design approach for smart } \\
\text { product-service systems using virtual reality: A } \\
\text { case study }\end{array}$ & $\begin{array}{l}\text { Journal of Cleaner } \\
\text { Production }\end{array}$ & 2021 \\
\hline 5 & $\begin{array}{l}\text { Chang, F.; Zhou, G.; Zhang, C.; } \\
\text { Ding, K.; Cheng, W.; Chang, F. }\end{array}$ & $\begin{array}{l}\text { A maintenance decision-making oriented } \\
\text { collaborative crossorganization knowledge } \\
\text { sharing blockchain network for complex } \\
\text { multi-component systems. }\end{array}$ & $\begin{array}{l}\text { Journal of Cleaner } \\
\text { Production }\end{array}$ & 2021 \\
\hline 6 & $\begin{array}{c}\text { Siguenza, C.P.; Cucurachi, S.; } \\
\text { Tukker, A. }\end{array}$ & $\begin{array}{l}\text { Circular business models of washing machines } \\
\text { in the Netherlands: Material and climate } \\
\text { change implications toward } 2050 .\end{array}$ & $\begin{array}{l}\text { Sustainable Production } \\
\text { and Consumption }\end{array}$ & 2021 \\
\hline 7 & $\begin{array}{l}\text { Joensuu, T.; Edelman, H.; } \\
\text { Saari, A. }\end{array}$ & $\begin{array}{c}\text { Circular economy practices in the built } \\
\text { environment }\end{array}$ & $\begin{array}{l}\text { Journal of Cleaner } \\
\text { Production }\end{array}$ & 2020 \\
\hline 8 & $\begin{array}{l}\text { Salwin, M.; Kraslawski, A.; } \\
\text { Lipiak, J.; Golebiewski, D.; } \\
\text { Andrzejewski, M. }\end{array}$ & $\begin{array}{l}\text { Product-service system business model for } \\
\text { printing houses }\end{array}$ & $\begin{array}{l}\text { Journal of Cleaner } \\
\text { Production }\end{array}$ & 2020 \\
\hline 9 & $\begin{array}{l}\text { Wang, N.; Ren, S.; Liu, Y.; } \\
\text { Yang, M.; Wang, J.; Huisingh, D. }\end{array}$ & $\begin{array}{c}\text { An active preventive maintenance approach of } \\
\text { complex equipment based on a novel } \\
\text { product-service system operation mode. }\end{array}$ & $\begin{array}{l}\text { Journal of Cleaner } \\
\text { Production }\end{array}$ & 2020 \\
\hline 10 & $\begin{array}{l}\text { Joensuu, T., Edelman, H., } \\
\text { Saari, A. }\end{array}$ & $\begin{array}{c}\text { Circular economy practices in the built } \\
\text { environment }\end{array}$ & $\begin{array}{l}\text { Journal of Cleaner } \\
\text { Production }\end{array}$ & 2020 \\
\hline 11 & $\begin{array}{l}\text { Ivanov, V.; Trojanowska, J.; } \\
\text { Pavlenko, I,; Zajac, J.; } \\
\text { Peraković, D. }\end{array}$ & $\begin{array}{c}\text { 3rd International Conference on Design, } \\
\text { Simulation, Manufacturing: The Innovation } \\
\text { Exchange, DSMIE } 2020\end{array}$ & $\begin{array}{l}\text { Lecture Notes in } \\
\text { Mechanical } \\
\text { Engineering }\end{array}$ & 2020 \\
\hline 12 & $\begin{array}{l}\text { Pacheco, D.A.J.; Caten, A.S.; } \\
\text { Jung, C.F.; Navas, H.V.G.; } \\
\text { Cruz-Machado, V.A.; } \\
\text { Tonetto, L.M. }\end{array}$ & $\begin{array}{c}\text { State of the art on the role of the Theory of } \\
\text { Inventive Problem Solving in Sustainable } \\
\text { Product-Service System: Past, Present } \\
\text { and Future. }\end{array}$ & $\begin{array}{l}\text { Journal of Cleaner } \\
\text { Production }\end{array}$ & 2019 \\
\hline
\end{tabular}


Table A1. Cont.

\begin{tabular}{|c|c|c|c|c|}
\hline$\#$ & Authors & Article Title & Journal & Year \\
\hline 13 & $\begin{array}{l}\text { Zhang, A.; Chai, N.; Ostrosi, E.; } \\
\text { Shang, Y. }\end{array}$ & $\begin{array}{c}\text { Extraction of association rules in the schematic } \\
\text { design of product service system based on } \\
\text { Pareto-MODGDFA }\end{array}$ & $\begin{array}{c}\text { Computers \& } \\
\text { Industrial Engineering }\end{array}$ & 2019 \\
\hline 14 & $\begin{array}{l}\text { Liu, B., Zhang, Y., Zhang, G., } \\
\text { Zheng, P. }\end{array}$ & $\begin{array}{l}\text { Edge-cloud orchestration driven industrial } \\
\text { smart product-service systems solution design } \\
\text { based on CPS and IIoT }\end{array}$ & $\begin{array}{l}\text { Advanced Engineering } \\
\text { Informatics }\end{array}$ & 2019 \\
\hline 15 & $\begin{array}{l}\text { Sousa-Zomer, T.T.; Magalhães, } \\
\text { L.; Zancul, E.; Campos, L.M.S.; } \\
\text { Cauchick-Miguel, P.A. }\end{array}$ & $\begin{array}{l}\text { Cleaner production as an antecedent for circular } \\
\text { economy paradigm shift at the micro-level: } \\
\text { Evidence from a home appliance manufacturer. }\end{array}$ & $\begin{array}{l}\text { Journal of Cleaner } \\
\text { Production }\end{array}$ & 2018 \\
\hline 16 & $\begin{array}{l}\text { Chang, F.; Zhou, G.; Xiao, X.; } \\
\text { Tian, C.; Zhang, C. }\end{array}$ & $\begin{array}{l}\text { A function availability-based integrated } \\
\text { product-service network model for high-end } \\
\text { manufacturing equipment }\end{array}$ & $\begin{array}{c}\text { Computers \& } \\
\text { Industrial Engineering }\end{array}$ & 2018 \\
\hline 17 & Zhang, G.; Sun, H. & $\begin{array}{l}\text { Enabling a cutting tool iPSS based on tool } \\
\text { condition monitoring }\end{array}$ & $\begin{array}{l}\text { International Journal of } \\
\text { Advanced } \\
\text { Manufacturing } \\
\text { Technology }\end{array}$ & 2018 \\
\hline 18 & Zhang, G.; Sun, H. & $\begin{array}{l}\text { Enabling cutting tool services based on } \\
\text { in-process machining condition monitoring }\end{array}$ & $\begin{array}{l}\text { International Journal of } \\
\text { Internet Manufacturing } \\
\text { and Services }\end{array}$ & 2018 \\
\hline 19 & Souza-Zomer et al. & $\begin{array}{l}\text { Cleaner production as an antecedent for circular } \\
\text { economy paradigm shift at the micro-level: } \\
\text { Evidence from a home appliance manufacturer }\end{array}$ & $\begin{array}{l}\text { Journal of Cleaner } \\
\text { Production }\end{array}$ & 2018 \\
\hline 20 & $\begin{array}{l}\text { Sopelana, N., Gonzalez, L., } \\
\text { Lazaro, O., Laskurain, A., } \\
\text { Minguez, R. }\end{array}$ & $\begin{array}{l}\text { Circular engineering and product-service } \\
\text { systems in the machine tool sector: The } \\
\text { PSYMBIOSYS approach }\end{array}$ & $\begin{array}{c}\text { Enterprise } \\
\text { Interoperability: Smart } \\
\text { Services and Business } \\
\text { Impact of Enterprise } \\
\text { Interoperability }\end{array}$ & 2018 \\
\hline 21 & $\begin{array}{l}\text { Mourtzis, D., Fotia, S., Boli, N., } \\
\text { Pittaro, P. }\end{array}$ & $\begin{array}{l}\text { Product-service system (PSS) complexity } \\
\text { metrics within mass customization and } \\
\text { Industry } 4.0 \text { environment }\end{array}$ & $\begin{array}{l}\text { International Journal of } \\
\text { Advanced } \\
\text { Manufacturing } \\
\text { Technology }\end{array}$ & 2018 \\
\hline 22 & $\begin{array}{l}\text { Peruzzini, M.; Pellicciari, M.; } \\
\text { Bil, C. }\end{array}$ & $\begin{array}{l}\text { 25th ISTE International Conference on } \\
\text { Transdisciplinary Engineering, } 2018\end{array}$ & $\begin{array}{l}\text { Advances in } \\
\text { Transdisciplinary } \\
\text { Engineering }\end{array}$ & 2018 \\
\hline 23 & $\begin{array}{l}\text { Sousa-Zomer, T.T.; Magalhães, } \\
\text { L.; Zancul, E.; } \\
\text { Cauchick-Miguel, P.A. }\end{array}$ & $\begin{array}{l}\text { Lifecycle management of product-service } \\
\text { systems: a preliminary investigation of a white } \\
\text { goods manufacturer }\end{array}$ & Procedia CIRP & 2017 \\
\hline 24 & $\begin{array}{c}\text { Wan, S.; Li, D.; Gao, J.; Roy, R.; } \\
\text { Tong, Y. }\end{array}$ & $\begin{array}{l}\text { Process and knowledge management in a } \\
\text { collaborative maintenance planning system for } \\
\text { high value machine tools }\end{array}$ & Computers in Industry & 2017 \\
\hline 25 & Auer, J.; Bey, N.; Schafer, J. & $\begin{array}{l}\text { Combined life cycle assessment and life cycle } \\
\text { costing in the eco-care-matrix: A case study on } \\
\text { the performance of a modernized maufacturing } \\
\text { system for glass containers. }\end{array}$ & $\begin{array}{l}\text { Journal of Cleaner } \\
\text { Production }\end{array}$ & 2017 \\
\hline 26 & Mu, H., Jiang, P., Leng, J. & $\begin{array}{l}\text { Costing-based coordination between mt-iPSS } \\
\text { customer and providers for job shop } \\
\text { production using game theory }\end{array}$ & $\begin{array}{l}\text { International Journal of } \\
\text { Production Research }\end{array}$ & 2017 \\
\hline 27 & $\begin{array}{l}\text { Uhlmann, E., Hohwieler, E., } \\
\text { Geisert, C. }\end{array}$ & $\begin{array}{c}\text { Intelligent production systems in the era of } \\
\text { industrie } 4.0 \text {-Changing mindsets and } \\
\text { business models }\end{array}$ & $\begin{array}{l}\text { Journal of Machine } \\
\text { Engineering }\end{array}$ & 2017 \\
\hline
\end{tabular}


Table A1. Cont.

\begin{tabular}{|c|c|c|c|c|}
\hline$\#$ & Authors & Article Title & Journal & Year \\
\hline 28 & $\begin{array}{l}\text { Sun, P., Zhang, C., Jiang, P., } \\
\text { Cao, W. }\end{array}$ & $\begin{array}{l}\text { Cutting-tool delivery method in the context of } \\
\text { industrial product service systems }\end{array}$ & $\begin{array}{l}\text { Concurrent } \\
\text { Engineering Research } \\
\text { and Applications }\end{array}$ & 2016 \\
\hline 29 & Weißfloch, U., Geldermann, J. & $\begin{array}{c}\text { Assessment of product-service systems for } \\
\text { increasing the energy efficiency of compressed } \\
\text { air systems }\end{array}$ & $\begin{array}{l}\text { European Journal of } \\
\text { Industrial Engineering }\end{array}$ & 2016 \\
\hline 30 & $\begin{array}{l}\text { Uhlmann, E., Gabriel, C., } \\
\text { Raue, N. }\end{array}$ & $\begin{array}{l}\text { An automation approach based on workflows } \\
\text { and software agents for industrial } \\
\text { product-service systems }\end{array}$ & Procedia CIRP & 2015 \\
\hline 31 & Selak, L.; Butala, P.; Sluga, A. & $\begin{array}{l}\text { Condition monitoring and fault diagnostics for } \\
\text { hydropower plants }\end{array}$ & Computers in Industry & 2014 \\
\hline 32 & $\begin{array}{l}\text { Settanni, E.; Newnes, L.B.; } \\
\text { Thenent, N.E.; Parry, G.; } \\
\text { Goh, Y.M. }\end{array}$ & $\begin{array}{l}\text { A through-life costing methodology for use in } \\
\text { product-service-systems }\end{array}$ & $\begin{array}{l}\text { International Journal of } \\
\text { Production Economics }\end{array}$ & 2014 \\
\hline 33 & [No author name available] & $\begin{array}{c}\text { IFIP WG } 5.7 \text { International Conference on } \\
\text { Advances in Production Management Systems, } \\
\text { APMS } 2014\end{array}$ & $\begin{array}{l}\text { IFIP Advances in } \\
\text { Information and } \\
\text { Communication } \\
\text { Technology }\end{array}$ & 2014 \\
\hline 34 & Liedtke, C., Buhl, J., Ameli, N. & $\begin{array}{l}\text { Microfoundations for sustainable growth with } \\
\text { eco-intelligent product service-arrangements }\end{array}$ & Sustainability & 2013 \\
\hline 35 & Lv, Z., Miao, R., Wang, S. & $\begin{array}{c}\text { The application of six sigma management in } \\
\text { product service system }\end{array}$ & $\begin{array}{c}\text { International Asia } \\
\text { Conference on } \\
\text { Industrial Engineering } \\
\text { and Management } \\
\text { Innovation: Core Areas } \\
\text { of Industrial } \\
\text { Engineering, IEMI } \\
\text { 2012-Proceedings }\end{array}$ & 2013 \\
\hline 36 & Mu, H.; Jiang, P.; Zhu, Q. & $\begin{array}{c}\text { Machining process level cost estimation in } \\
\text { cutting-tool IPSS }\end{array}$ & $\begin{array}{l}\text { Applied Mechanics and } \\
\text { Materials }\end{array}$ & 2012 \\
\hline 37 & $\begin{array}{l}\text { Vezzoli, C., Ceschin, F., } \\
\text { Diehl, J.C., Kohtala, C. }\end{array}$ & $\begin{array}{c}\text { Why have 'Sustainable Product-Service } \\
\text { Systems' not been widely implemented? } \\
\text { Meeting new design challenges to achieve } \\
\text { societal sustainability }\end{array}$ & $\begin{array}{l}\text { Journal of Cleaner } \\
\text { Production }\end{array}$ & 2012 \\
\hline 38 & $\begin{array}{l}\text { Lelah, A.; Mathieux, F.; } \\
\text { Brissaud, D. }\end{array}$ & $\begin{array}{l}\text { Contributions to eco-design of } \\
\text { machine-to-machine product service systems: } \\
\text { the example of waste glass collection. }\end{array}$ & $\begin{array}{l}\text { Journal of Cleaner } \\
\text { Production }\end{array}$ & 2011 \\
\hline 39 & $\begin{array}{l}\text { Schuh, G., Potente, T., } \\
\text { Schittny, B., Wittek, A. }\end{array}$ & $\begin{array}{c}\text { Industrial product-service-systems for the } \\
\text { tooling industry }\end{array}$ & $\begin{array}{l}\text { 17th International } \\
\text { Conference on } \\
\text { Concurrent } \\
\text { Enterprising, ICE } \\
\text { 2011-Conference } \\
\text { Proceedings }\end{array}$ & 2011 \\
\hline 40 & Zhu, Q.Q., Jiang, P.Y. & $\begin{array}{c}\text { Machining capacity measurement of an } \\
\text { industrial product service system for turning } \\
\text { processg }\end{array}$ & $\begin{array}{l}\text { Proceedings of the } \\
\text { Institution of } \\
\text { Mechanical Engineers, } \\
\text { Part B: Journal of } \\
\text { Engineering } \\
\text { Manufacture }\end{array}$ & 2011 \\
\hline
\end{tabular}


Table A1. Cont.

\begin{tabular}{|c|c|c|c|c|}
\hline$\#$ & Authors & Article Title & Journal & Year \\
\hline 41 & $\begin{array}{l}\text { Sun, H., Wan, N., } \\
\text { Chang, Z., Mo, R. }\end{array}$ & $\begin{array}{l}\text { Approach to optimization of part machining } \\
\text { service combination }\end{array}$ & $\begin{array}{c}\text { International Journal of } \\
\text { Advanced } \\
\text { Manufacturing } \\
\text { Technology }\end{array}$ & 2011 \\
\hline 42 & Abramovici, M., Lindner, A. & $\begin{array}{l}\text { Providing product use knowledge for the } \\
\text { design of improved product generations }\end{array}$ & $\begin{array}{l}\text { CIRP Annals- } \\
\text { Manufacturing } \\
\text { Technology }\end{array}$ & 2011 \\
\hline 43 & $\begin{array}{l}\text { Zhu, Q.Q., Jiang, P.Y., } \\
\text { Huang, G.Q., Qu, T. }\end{array}$ & $\begin{array}{l}\text { Implementing an industrial product-service } \\
\text { system for CNC machine tool }\end{array}$ & $\begin{array}{c}\text { International Journal of } \\
\text { Advanced } \\
\text { Manufacturing } \\
\text { Technology }\end{array}$ & 2011 \\
\hline 44 & Zhu, Q., Jiang, P. & $\begin{array}{l}\text { Operations of an industrial product service } \\
\text { system based on machine tool at user factory }\end{array}$ & $\begin{array}{c}\text { Proceedings-2010 } \\
\text { International } \\
\text { Conference on Digital } \\
\text { Manufacturing and } \\
\text { Automation, ICDMA } \\
2010\end{array}$ & 2010 \\
\hline
\end{tabular}

Proceedings of the 10th International

Conference of the

45

Uhlmann, E., Geisert, C., Stelzer, C.
Software agent based monitoring for a micro milling spindle
European Society for

Precision Engineering

and Nanotechnology,

EUSPEN 2010

International Journal of

Internet Manufacturing and Services

tool

Sustainability

2009

Design for sustainability: Current trends in
sustainable product design and developmen Crul, M.

48

Zhu, Q.-Q., Jiang, P.-Y., Zhang, P., Wang, X.-X.

Configuration and operation architecture for product service systems of CNC machine tools

Jisuanji Jicheng Zhizao

Xitong/Computer Integrated
Manufacturing Systems, CIMS

\section{International}

Conference on

Computers and service-oriented manufacturing executivesystems

Industrial Engineering, CIE 2009

A new conceptual architecture to enable iPSS as International Journal of a key for service-oriented manufacturing Internet Manufacturing executive systems and Services

International Journal of

Computer Integrated

A knowledge management framework to
support product-service systems design Manufacturing

1st EU-Korea Conference on Science and Springer Proceedings Technology, EKC 2008 in Physics

Life Cycle Design: from general methods to product type specific guidelines and checklists:

Vezzoli, C.; Sciama, D.
Journal of Cleaner

Production a method adopted to develop a set of guidelines/checklist handbook for the eco-efficient design of NECTA vending machines. 
Table A1. Cont.

\begin{tabular}{ccccc}
\hline$\#$ & Authors & Article Title & Journal & Year \\
\hline 54 & Mont, O. & $\begin{array}{c}\text { Editorial for the special issue of the Journal of } \\
\text { Cleaner Production on Product Service Systems }\end{array}$ & $\begin{array}{c}\text { Journal of Cleaner } \\
\text { Production }\end{array}$ & $\begin{array}{c}\text { 2003 } \\
\text { Production }\end{array}$ \\
\hline 55 & Maxwell, D.; Van der Vorst, R. & Developing sustainable products and services & Journal of Cleaner & Industry and \\
Environment & 2003 \\
\hline 56 & Solgaard, A. & Promoting a life-cycle approach & Futures & 2000 \\
\hline
\end{tabular}

\section{References}

1. Wang, N.; Ren, S.; Liu, Y.; Yang, M.; Wang, J.; Huisingh, D. An active preventive maintenance approach of complex equipment based on a novel product-service system operation mode. J. Clean. Prod. 2020, 277, 123365. [CrossRef]

2. Manzini, E.; Vezzoli, C. A strategic design approach to develop sustainable product service systems: Examples taken from the environmentally friendly innovation' Italian prize. J. Clean. Prod. 2003, 11, 851-857. [CrossRef]

3. Mu, H.; Jiang, P.; Zhu, Q. Machining Process Level Cost Estimation in Cutting-Tool IPSS. Appl. Mech. Mater. 2012, 101, 759-762. [CrossRef]

4. Fargnoli, M.; Haber, N.; Sakao, T. PSS modularisation: A customer-driven integrated approach. Int. J. Prod. Res. 2019, 57, 4061-4077. [CrossRef]

5. $\quad$ Baines, T.S.; Lightfoot, H.W.; Evans, S.; Neely, A.; Greenough, R.; Peppard, J.; Roy, R.; Shehab, E.; Braganza, A.; Tiwari, A.; et al. State-of-the-art in product-service systems. Proc. Inst. Mech. Eng. Part B J. Eng. Manuf. 2007, 221, 1543-1552. [CrossRef]

6. Zhang, G.; Sun, H. Enabling a cutting tool iPSS based on tool condition monitoring. Int. J. Adv. Manuf. Technol. 2018, 94, 3265-3274. [CrossRef]

7. Fargnoli, M.; Costantino, F.; Di Gravio, G.; Tronci, M. Product service-systems implementation: A customized framework to enhance sustainability and customer satisfaction. J. Clean. Prod. 2018, 188, 387-401. [CrossRef]

8. Farsi, M.; Erkoyuncu, J.A. An agent-based approach to quantify the uncertainty in Product-Service System contract decisions: A case study in the machine tool industry. Int. J. Prod. Econ. 2021, 233, 108014. [CrossRef]

9. Zhang, Z.; Chai, N.; Ostrosi, E.; Shang, Y. Extraction of association rules in the schematic design of product service system based on Pareto-MODGDFA. Comput. Ind. Eng. 2019, 129, 392-403. [CrossRef]

10. Chang, F.; Zhou, G.; Zhang, C.; Ding, K.; Cheng, W.; Chang, F. A maintenance decision-making oriented collaborative crossorganization knowledge sharing blockchain network for complex multi-component systems. J. Clean. Prod. 2021, $282,124541$. [CrossRef]

11. Chang, F.; Zhou, G.; Xiao, X.; Tian, C.; Zhang, C. A function availability-based integrated product-service network model for high-end manufacturing equipment. Comput. Ind. Eng. 2018, 126, 302-316. [CrossRef]

12. Wan, S.; Li, D.; Gao, J.; Roy, R.; Tong, Y. Process and knowledge management in a collaborative maintenance planning system for high value machine tools. Comput. Ind. 2017, 84, 14-24. [CrossRef]

13. Sun, P.; Zhang, C.; Jiang, P.; Cao, W. Cutting-tool delivery method in the context of industrial product service systems. Concurr. Eng. Res. Appl. 2016, 25, 178-190. [CrossRef]

14. Zhu, Q.Q.; Jiang, P.Y.; Huang, G.Q.; Qu, T. Implementing an industrial product-service system for CNC machine tool. Int. J. Adv. Manuf. Technol. 2011, 52, 1133-1147. [CrossRef]

15. Oliveira Neto, G.C.; Correia, J.M.F.; Silva, P.C.; Sanches, A.G.O.; Lucato, W.C. Cleaner Production in the textile industry and its relationship to sustainable development goals. J. Clean. Prod. 2019, 228, 1514-1525. [CrossRef]

16. Leite, R.R.; Amorim, M.P.C.; Rodrigues, M.J.F.; Neto, G.C.O. Overcoming Barriers for Adopting Cleaner Production: A Case Study in Brazilian Small Metal-Mechanic Companies. Sustainability 2019, 11, 4808. [CrossRef]

17. Paoli, F.M.; Oliveira Neto, G.C.; Lucato, W.C. Economic and environmental gains resulting from the utilization of the design for the environment (DfE). Espacios 2013, 34, 11.

18. Neto, G.C.O.; Tucci, H.N.P.; Correia, J.M.F.; Silva, V.H.C.; Ganga, G.M.D. Assessing the implementation of Cleaner Production and company sizes: Survey in textile companies. J. Eng. Fibers Fabr. 2020, 15, 15. [CrossRef]

19. Silva, P.C.; Neto, G.C.O.; Correia, J.M.F.; Tucci, H.N.P. Evaluation of economic, environmental and operational performance of the adoption of cleaner production: Survey in large textile industries. J. Clean. Prod. 2021, 278, 123855. [CrossRef]

20. Oliveira Neto, G.C.; Tucci, H.N.P.; Correia, J.M.F.; Da Silva, P.C.; Da Silva, D.; Amorim, M.P.C. Stakeholders' influences on the adoption of cleaner production practices: A survey of the textile industry. Sustain. Prod. Consum. 2021, 26, 126-145. [CrossRef]

21. Oliveira Neto, G.C.; Pinto, L.F.R. Drivers to Promote Sustainability as Operational Strategy: Cross Content Analysis. J. Environ. Account. Manag. 2019, 7, 395-408. [CrossRef]

22. Awan, U.; Khattak, A.; Rabbani, S.; Dhir, A. Buyer-Driven Knowledge Transfer Activities to Enhance Organizational Sustainability of Suppliers. Sustainability 2020, 12, 2993. [CrossRef] 
23. Doni, F.; Corvino, A.; Martini, S.B. Servitization and sustainability actions. Evidence from European manufacturing companies. J. Environ. Manag. 2019, 234, 367-378. [CrossRef]

24. Pinto, L.F.R.; Neto, G.C.O.; Mummolo, G.; Digiesi, S.; Facchini, F.; Centoamore, P. Cleaner Production Initiatives in a Diesel Engines Factory. Int. J. Ind. Eng. Manag. 2020, 11, 73-80. [CrossRef]

25. Babaei, M.; Abazari, A.; Muyeen, S.M. Coordination between Demand Response Programming and Learning-Based FOPID Controller for Alleviation of Frequency Excursion of Hybrid Microgrid. Energies 2020, 13, 442. [CrossRef]

26. Knecht, W.; Lakshminarayanan, P.A. Modern Diesel Combustion. In Design and Development of Heavy Duty Diesel Engines. Energy, Environment, and Sustainability; Lakshminarayanan, P., Agarwal, A., Eds.; Springer: Singapore, 2020. [CrossRef]

27. Sun, J.; Zhao, J.; Huang, Z.; Yan, K.; Shen, X.; Xing, J.; Gao, Y.; Jian, Y.; Yang, H.; Li, B. A Review on Binderless Tungsten Carbide: Development and Application. Nano Micro Lett. 2020, 12, 1-37. [CrossRef] [PubMed]

28. Shemi, A.; Magumise, A.; Ndlovu, S.; Sacks, N. Recycling of tungsten carbide scrap metal: A review of recycling methods and future prospects. Miner. Eng. 2018, 122, 195-205. [CrossRef]

29. Bach, V.; Finogenova, N.; Berger, M.; Winter, L.; Finkbeiner, M. Enhancing the assessment of critical resources use at the country level with the SCARCE method-Case study of Germany. Resour. Policy 2017, 53, 283-299. [CrossRef]

30. Sverdrup, H.U.; Ragnarsdottir, K.V.; Koca, D. An assessment of metal supply sustainability as an input to policy: Security of supply extraction rates, stocks-in-use, recycling, and risk of scarcity. J. Clean. Prod. 2017, 140, 359-372. [CrossRef]

31. Begum, S.; Xia, E.; Ali, F.; Awan, U.; Ashfaq, M. Achieving green product and process innovation through green leadership and creative engagement in manufacturing. J. Manuf. Technol. Manag. 2021. [CrossRef]

32. Voss, C.; Tsikriktsis, N.; Frohlich, M. Case research in operations management. Int. J. Oper. Prod. Manag. 2002, 22, 195-219. [CrossRef]

33. Yin, R.K. Case Study Research: Design and Methods, 4th ed.; Sage: Newbury Park, CA, USA, 2009.

34. Cooper, H.M.; Lindsay, J.L. Research Synthesis and Meta-Analysis. Handbook of Applied Social Research Methods; Sage: Thousand Oaks, CA, USA, 1998.

35. Moher, D.; Liberati, A.; Tetzlaff, J.; Altman, D.G. Reprint-Preferred reporting items for systematic reviews and meta-analyses: The PRISMA statement. Phys. Ther. 2009, 89, 873-880. [CrossRef]

36. Davis, J.; Mengersen, K.; Bennett, S.; Mazerolle, L. Viewing systematic reviews and meta-analysis in social research through different lenses. SpringerPlus 2014, 3, 511. [CrossRef]

37. Baumeister, R.F.; Leary, M.R. Writing Narrative Literature Reviews. Rev. Gen. Psychol. 1997, 1, 311-320. [CrossRef]

38. Di Vaio, A.; Palladino, R.; Hassan, R.; Escobar, O. Artificial intelligence and business models in the sustainable development goals perspective: A systematic literature review. J. Bus. Res. 2020, 121, 283-314. [CrossRef]

39. Bardin, L. El Analisis de Contenido; Ediciones Akal: Madrid, Spain, 1986.

40. Aghaei, C.A.; Salehi, H.; Yunus, M.; Farhadi, H.; Fooladi, M.; Farhadi, M.; Ebrahim, N.A. A comparison between two main academic literature collections: Web of Science and Scopus databases. Asian Soc. Sci. 2013, 9, 18-26.

41. Rosa, P.; Sassanelli, C.; Urbinati, A.; Chiaroni, D.; Terzi, S. Assessing relations between Circular Economy and Industry 4.0: A systematic literature review. Int. J. Prod. Res. 2020, 58, 1662-1687. [CrossRef]

42. Fahimnia, B.; Sarkis, J.; Davarzani, H. Green supply chain management: A review and bibliometric analysis. Int. J. Prod. Econ. 2015, 162, 101-114. [CrossRef]

43. Cillo, V.; Petruzzelli, A.M.; Ardito, L.; Del Giudice, M. Understanding sustainable innovation: A systematic literature review. Corp. Soc. Responsib. Environ. Manag. 2019, 26, 1012-1025. [CrossRef]

44. Del Giudice, M.; Di Vio, A.; Hassan, R.; Palladino, R. Digitalization and new technologies for sustainable business models at the ship-port interface: A bibliometric analysis. Marit. Policy Manag. 2021, 1-37. [CrossRef]

45. Sousa-Zomer, T.T.; Magalhães, L.; Zancul, E.; Campos, L.M.S.; Cauchick-Miguel, P.A. Cleaner production as an antecedent for circular economy paradigm shift at the micro-level: Evidence from a home appliance manufacturer. J. Clean. Prod. 2018, 185, 740-748. [CrossRef]

46. Joensuu, T.; Edelman, H.; Saari, A. Circular economy practices in the built environment. J. Clean. Prod. 2020, $276,124215$. [CrossRef]

47. Pecorari, P.M.; Lima, C.R.C. Correlation of customer experience with the acceptance of product-service systems and circular economy. J. Clean. Prod. 2021, 281, 125275. [CrossRef]

48. Chiu, M.; Huang, J.; Gupta, S.; Akman, G. Developing a personalized recommendation system in a smart product service system based on unsupervised learning model. Comput. Ind. 2021, 128, 103421. [CrossRef]

49. Vezzoli, C.; Sciama, D. Life Cycle Design: From general methods to product type specific guidelines and checklists: A method adopted to develop a set of guidelines/checklist handbook for the eco-efficient design of NECTA vending machines. J. Clean. Prod. 2006, 14, 1319-1325. [CrossRef]

50. Lelah, A.; Mathieux, F.; Brissaud, D. Contributions to eco-design of machine-to-machine product service systems: The example of waste glass collection. J. Clean. Prod. 2011, 19, 1033-1044. [CrossRef]

51. Settanni, E.; Newnes, L.B.; Thenent, N.E.; Parry, G.; Goh, Y.M. A through-life costing methodology for use in product-servicesystems. Int. J. Prod. Econ. 2014, 153, 161-177. [CrossRef] 